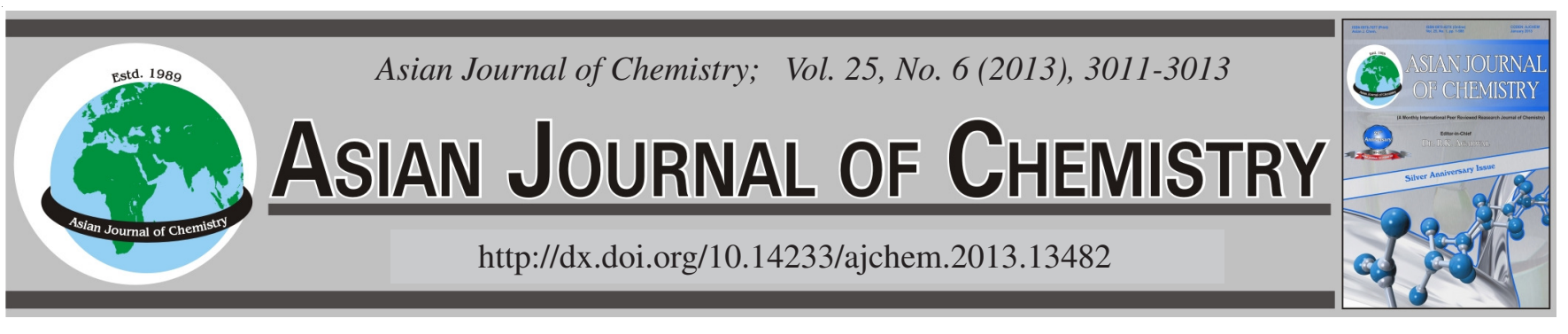

\title{
Antioxidant Properties and Total Phenolic Content of Two Solvent Extraction Extracts of Some Plants Belong to Labiatae Family
}

\author{
Fahad Al-Juhaimi ${ }^{1}$, Coskun Saglam ${ }^{2}$ and Mehmet Musa Özcan ${ }^{3, *}$
}

\begin{abstract}
${ }^{1}$ Department of Food Science \& Nutrition, College of Food and Agricultural Sciences, King Saud University, Riyadh, Saudi Arabia ${ }^{2}$ Selcuk University, Cumra High Educational College, 42500 Çumra, Konya, Turkey

${ }^{3}$ Department of Food Engineering, Faculty of Agriculture, Selcuk University, 42079 Konya, Turkey

*Corresponding author: Fax: +90 332 2410108; Tel: +90 332 2232933; E-mail: mozcan@ selcuk.edu.tr
\end{abstract}

\begin{abstract}
In vitro radical scavenging activity and the total phenolic content (Folin-Ciocalteu method) of two solvents (methanolic and ethyl acetate) extracts of some plants grown in Turkey were studied by using 1,1-diphenyl-2-picrylhydrazyl (DPPH) scavenging assay. Although the total phenolic content of the ethyl acetate extract of $R$. officinalis ( $41.8 \mathrm{mg} \mathrm{GAE} / \mathrm{g}$ dry weight) is higher than that of $L$. angustifolia (12.7 mg GAE/g dry weight), the corresponding radical scavenging activity of $R$. officinalis $(19.3 \%)$ is higher than those of other plants. The total phenolic content of the methanolic extract of $R$. officinalis ( $34.8 \mathrm{mg} \mathrm{GAE} / \mathrm{g}$ dry weight) is higher than those of other plant species. At the same time, its corresponding antioxidant activity is higher $(21.8 \%)$. It was established that there was positive linear correlation between radical scavenging activity and total phenolic contents.
\end{abstract}

Key Words: Herbs, Labiatae, Antioxidant activity, DPPH, Phenolic content.

\section{INTRODUCTION}

Antioxidants are important in prevention of pollution damage of plants, disease prevention in both plants and animals and play an important role in the body defense system and reactive oxygen species ${ }^{1-6}$. Shahidi et al. ${ }^{7}$, reported that the antioxidant effect of aromatic plants is due to the presence of hydroxyl groups in their phenolic compounds. Lagouri et al. ${ }^{8}$, studied the antioxidant activity of essential oils and they found that oregano essential oil, rich in thymol and carvacrol, has a considerable antioxidant effect on the process of lard oxidation. Politeo et al. ${ }^{9}$ analyzed the chemical compositions and related total antioxidant capacities of 12 spice essential oils. Recently, the use of spices and herbs as antioxidants against in foods is becoming of increasing importance. Antioxidants have been widely used as food additives to provide protection against oxidative degradation of foods ${ }^{9-12}$. The antioxidant properties of many aromatic spices and herbs are recorded to be effective in this role ${ }^{9,10}$. The aim of this study was to investigate their total phenolic content and antioxidant activity of some aromatic plants extracted by methanol and ethyl acetate solvents.

\section{EXPERIMENTAL}

Plants were obtained from of medicinal and aromatic plant program of S.Ü. Çumra Vocational High School in Konya in
Turkey. In addition, Thymbra spicata and Salvia aucheri were collected from Taurus mountain in Mersin (Gülnar) province. After plants were dried on shade, they were stored in a dry, dark and cool room. They were grounded before anayses.

Extraction: For both methanolic and ethyl acetate extraction, a $1 \mathrm{~g}$ aliquot of each the air-dried and ground plant species was extracted with $40 \mathrm{~mL}$ of methanol (Merck, Darmstadt, Germany) at $40^{\circ} \mathrm{C}$ for $4 \mathrm{~h}$ in a shaking water bath. After cooling, the extract was centrifuged at $4000 \mathrm{rpm}$ for $10 \mathrm{~min}$ and the supernatant was determined and stored at $4{ }^{\circ} \mathrm{C}$ by using for the DPPH and total phenolic content assay ${ }^{10,13}$.

Radical scavenging activity: The antioxidant activity of plant extracts was measured in terms of hydrogen donating or radical scavenging ability, using the stable radical DPPH method $^{14}$. Briefly, $100 \mu \mathrm{L}$ of various concentrations of the extract in methanol were added to $10 \mathrm{~mL}$ of a methanol solution of DPPH (1.01.10-2). The mixture was vigorously shaken and then allowed to stand at room temperature for $0.5 \mathrm{~h}$ in the dark. The absorbance of the mixture was measured at $517 \mathrm{~nm}$ by using spectrophotometer. A mixture of $100 \mu \mathrm{L}$ of methanol and $10 \mathrm{~mL}$ of DPPH solution was used as the control. The scavenging activity on the DPPH radical was expressed as inhibition percentage.

Total phenol: The total phenolic content was determined spectrophotometrically using the Folin-Ciocalteu method, 
based on the procedure of Singleton and Rossi ${ }^{14}$, using gallic acid as a standard phenolic compound. $50 \mu \mathrm{L}$ of the filtered extracts were mixed with $450 \mu \mathrm{L}$ of distilled water and $2.5 \mathrm{~mL}$ of $0.2 \mathrm{~N}$ Folin-Ciocalteu reagent. After $8 \mathrm{~min}, 300 \mu \mathrm{L}$ of saturated sodium carbonate solution $(25 \%)$ was added. The absorbance was measured a $765 \mathrm{~nm}$ after incubation at $35^{\circ} \mathrm{C}$ for $1.5 \mathrm{~h}$ with intermittent shaking. The calibration curve was prepared with gallic acid solutions ranging from $0-500 \mathrm{mg} / \mathrm{L}$ and the results are given as gallic acid equivalents (GAE).

Statistical analyses: Results of the research were analyzed for statistical significance by analysis of variance ${ }^{15}$.

\section{RESULTS AND DISCUSSION}

Changes in the DPPH radical scavenging activity of some commercial herb extracts for different solvent extractions are shown in Table-1. An increase in radical-scavenging activity was found in rosemary, followed by $S$. fruticosa, S. crypthantha, S. aucheri, T. spicata, O. vulgare, O. minimum and L. angustifolia for methanolic extraction. In addition, for ethyl acetate extraction, the highest radical-scavenging activity was recorded in $R$. officinalis, followed by $S$. fruticosa, T. spicata, $S$. chryptantha, S. aucheri, O. vulgare and O. minimum. As observed, the highest DPPH radical scavenging activity (21.87 and $19.36 \%$ ) was established for both methanolic and ethyl acetate solvent extraction, respectively. The radical scavenging activities of methanolic extracts of herbs were determined between $2.73 \%$ (L. angustifolia) to $21.87 \%$ (R. officinalis). For ethyl acetate extracts, these values were found between $2.97 \%$ (L. angustifolia) to $19.36 \%$ (R. officinalis). Generally, radical-scavenging activity of ethyl acetate extract was found higher than those of methanolic extracts. According to Jayaprakasha et al. ${ }^{16}$, the antioxidant activity of extracts depended on the presence of polyphenols may act as reductans. Javanmardi et $a l .^{5}$ determined the free radical scavenging activities of the aqueous extracts of Origanum vulgare L., $R$. officinalis and S. officinalis obtained from Finland. They reported the results as $0.335,0.236$ and $0.265\left[\mathrm{IC}_{50}(\mathrm{mg} / \mathrm{mL})\right]$, respectively.

Total phenolic contents of both solvent extracts of plants are presented in Table-1. Total phenolic content was estimated by the Folin-Ciocalteu colorimetric method, based the procedure of Singleton and Rossi ${ }^{14}$. Gallic acid $(1 \mathrm{mg} / \mathrm{mL})$ in methanol was used as the standard and absorbance will be recorded at $750 \mathrm{~nm}$. The total phenolic content was described as gallic acid equivalents (GAE) in $\mathrm{mg}$ per $\mathrm{g}$ dry material. As shown in Table-1, there is a large differences in the total phenolic content of the plant species determined, ranging from 10.2-34.8 mg GAE/g dry weight and from 12.7-41.8 mg GAE/ $\mathrm{g}$ dry weight for those of methanolic and ethyl acetate extracts, respectively. The most of plants showed remarkably high total phenolic content. For methanolic extracts, $R$. officinalis and $S$. fruticosa exhibited the highest total phenolic contents of 34.8 and $26.4 \mathrm{mg}$ GAE/g dry weight, while $R$. officinalis and T. spicata were the highest (with 41.8 and 21.4 mg GAE/g dry weight), respectively. L. angustifolia is the lowest in total phenolic content of both methanolic and ethyl acetate extracts (10.2 and $12.7 \mathrm{mg}$ GAE/g dry weight), respectively. The total phenolic content of aqueous and methanolic extracts of the investigated plant species ranged from 2.8-70.3 and from 2.6-59.6 mg GAE/g dry weight, respectively, while the total antioxidant capacity ranged from 12.9-731 and from 10.1-720 micromol TE/g dry weight, respectively ${ }^{10}$. In other study, the global polyphenols concentration of carob tree leaves ranged from 0.45-2.64 (g/L GAE) in the three categories of the extracts. In each variety (carob), ethyl acetate fraction exhibited the highest antioxidant activity compared to other fractions ${ }^{17}$. Politeo et al. ${ }^{9}$ reported that clove, basil and laurel could be used as a potential source of natural antioxidants with possible applications in food systems according to the three different (DPPH, FRAP and TBARS) methods. Also, these results were consistent with the results of many researchers who recorded such positive correlation between total phenolic content and antioxidant activity ${ }^{10,17,18}$.

The results obtained by the use of DPPH method showed that some of these herbs can be considered good sources of natural antioxidants. This may be attributed either to high percentage of the main constituents or so synergy among different oil constituents ${ }^{9}$. There was a positive linear correlation between radical scavenging activity and total phenolic content for methanolic and ethyl acetate extracts. These results suggested that the phenolic compounds contributed significantly to the antioxidant capacity of the studied plants. Rosemary ( $R$. officinalis) is used for its antiseptic and antispasmodic effects and a diuretic, carminative and to stimulate bile flow ${ }^{19,20}$.

\section{ACKNOWLEDGEMENTS}

This work was supported by Selçuk University Scientific Research Project (S.U.-BAP. Konya, Turkey).

TABLE-1

ANTIOXIDANT EFFECT AND TOTAL PHENOLIC CONTENTS OF SOME PLANT EXTRACTS

\begin{tabular}{lcccc}
\hline \multirow{2}{*}{ Plants } & \multicolumn{2}{c}{ Radical scavenging activity $(\%)$} & \multicolumn{2}{c}{ Total phenolic contents (mg GAE/g) } \\
\cline { 2 - 5 } & Methanolic extract & Ethhyl acetate extract & Methanolic extract & Ethhyl acetate extract \\
\hline L. angustifolia & $2.73 \pm 0.7^{*} \mathrm{e}$ & $2.97 \pm 0.3 \mathrm{e}$ & $10.2 \pm 0.9 \mathrm{e}$ & $12.7 \pm 0.3 \mathrm{~d}$ \\
O. vulgare & $13.73 \pm 2.6 \mathrm{~b} * *$ & $14.47 \pm 1.6 \mathrm{~b}$ & $18.9 \pm 0.3 \mathrm{c}$ & $21.3 \pm 0.9 \mathrm{~b}$ \\
M. spicata & $4.81 \pm 1.3 \mathrm{~d}$ & $6.75 \pm 0.9 \mathrm{~d}$ & $18.7 \pm 1.8 \mathrm{c}$ & $19.8 \pm 0.9 \mathrm{bc}$ \\
R. officinalis & $21.87 \pm 1.9 \mathrm{a}$ & $19.36 \pm 2.1 \mathrm{a}$ & $34.8 \pm 2.6 \mathrm{a}$ & $41.8 \pm 1.4 \mathrm{a}$ \\
S. fruticosa & $16.13 \pm 2.1 \mathrm{~b}$ & $17.87 \pm 0.7 \mathrm{ab}$ & $26.4 \pm 1.3 \mathrm{~b}$ & $16.7 \pm 0.7 \mathrm{bc}$ \\
S. crypthantha & $15.78 \pm 1.9 \mathrm{~b}$ & $15.43 \pm 1.2 \mathrm{~b}$ & $18.7 \pm 0.9 \mathrm{c}$ & $19.4 \pm 0.3 \mathrm{~b}$ \\
O. minimum & $11.43 \pm 1.4 \mathrm{c}$ & $11.18 \pm \pm 1.6 \mathrm{bc}$ & $14.4 \pm 0.7 \mathrm{~d}$ & $16.3 \pm 0.5 \mathrm{bc}$ \\
T. spicata & $14.13 \pm 1.8 \mathrm{~b}$ & $15.78 \pm 2.3 \mathrm{~b}$ & $23.7 \pm 0.4 \mathrm{~b}$ & $21.4 \pm 1.2 \mathrm{~b}$ \\
S. aucheri & $14.73 \pm 1.1 \mathrm{~b}$ & $15.41 \pm 2.1 \mathrm{~b}$ & $16.9 \pm 0.7 \mathrm{bc}$ & $17.2 \pm 0.9 \mathrm{bc}$ \\
\hline "Vac
\end{tabular}

$*$ Values are reported as mean $\pm \mathrm{SD}$ of three replications. **Means within a column with different superscript are significantly different at $p<0.05$. 


\section{REFERENCES}

1. D.O. Huang, M. Hampsch-Woodil, A. Judith and K.D. Flanagon-Elizabeth, J. Agric. Food Chem., 50, 3122 (2002).

2. D. Mantle, F. Eddeb and A.T. Pickering, J. Ethnopharm., 72, 47 (2000).

3. M.A. Gyamfi, M. Yonamine and Y. Aniya, General Pharm., 32, 661 (1999)

4. H.J.D. Dorman, A. Peltoketo, R. Hiltunen and M.J. Tikkanen, Food Chem., 83, 255 (2003).

5. J. Javanmardi, C. Stushnoff, E. Locke and J.M. Vivanco, Food Chem., 83, 547 (2003)

6. S. Ahmed and S.H. Beigh, J. Med. Biol. Sci., 3, 1 (2009).

7. F. Shahidi, P.K. Janitha and P.D. Wanasundara, Critic. Rev. Food Sci. Nutri., 32, 67 (1992).

8. V. Lagouri, G. Blekas, M. Tsimidou, S. Kokkini and D. Boskou, Z. Lebensm Unt. Forsch., 197, 20 (1993).

9. M. Elmastas, I. Gncin, L. Qzturk and I. Gokce, Asian J. Chem., 17, 137 (2005).
10. K. Tawaha, F.Q. Alali, M. Gharaibeh, M. Mohammad and T. El-Elimat, Food Chem., 104, 1372 (2007).

11. M.M. Özcan and F. Al-Juhaimi, J. Med. Plants Res., 5, 1361 (2011).

12. Y.S. Velioglu, G. Mazza, L. Gao and B.D. Oomah, J. Agric. Food Chem., 46, 4113 (1998).

13. H. El-Hajaji, N. Lachkar, K. Alaoui, Y. Cherrah, A. Farah, A. Ennabili, B. El-Bali and M. Lachkar, Records Nat. Prod., 4, 193 (2010).

14. V.L. Singleton and J.A. Rossi, Am. J. Enol. Vit., 16, 144 (1965).

15. H. Püskülcü, F. Ikiz, Introduction to Statistic. Bilgehan Press, Bornova, Izmir, Turkey, p. 333, (1989) (in Turkish)

16. G.K. Jayaprakasha, T. Selvi and K.K. Sakariah, Food Res. Int., 36, 117 (2003).

17. Y. Cai, Q Luo, M. Sun and H. Corke, Life Sci., 74, 2157 (2004).

18. W. Zheng and S.Y. Wang, J. Agric. Food Chem., 49, 5165 (2001).

19. F.M. Karim and S.A. Quraan, Medicinal Plants of Jordan, Yarmauk University, Irbid, Jordan (1986).

20. S. Al-Khalil, Int. J. Pharm., 33, 317 (1995). 